\title{
David Oliver: How much information should patients' families expect on acute wards?
}

\author{
David Oliver consultant in geriatrics and acute general medicine
}

Berkshire

One of the biggest stressors in work for me and my colleagues, junior and senior, is the relentless demand for information-not from patients themselves but from their relatives.

It's taboo to talk about this in public for fear of appearing callous and uncaring. But it comes up whenever a group of medics unburden themselves in a safe space. I'm happy to break the taboo and to be found wanting for doing so.

The source of this stress is rarely visitors who are involved carers, supporting the patient day in, day out. They are often highly present on the wards, making frequent interaction and updates easier. It's crucial to involve these carers as we plan care jointly and make key decisions. ${ }^{12}$ But other visitors, who may be more distantly involved or geographically distant, often arrive at evenings and weekends when the regular ward staff aren't there. They can struggle to get the information and updates they seek or may get it second hand from less well informed staff.

\section{It's taboo to talk about this in public for fear of appearing callous and uncaring}

We could, I guess, match the timing of medical staff shifts to times of peak visitor requests for updates. But, as the patients themselves should be central, could we justify the opportunity cost for their care, running the wards with a depleted daytime team?

We have lots of less visible work to do away from our main inpatient wards, but I'd estimate that NHS doctors, especially consultants, could easily spend three to four hours a day, every weekday - maybe in a high visibility "DOCTOR" jacket in the middle of the ward-talking to patients' families.

During the evening and at weekends, junior doctors often cover several wards and try to review numerous patients, some of whom are very unwell, while also struggling with endemic rota gaps. ${ }^{34}$ They may be repeatedly approached by relatives desperate for information, who think that this can come only from a doctor. As a result, junior doctors can't get on with the jobs they've arrived on the ward to do.

We should manage the public's expectations in this area better: this includes public information in ward areas about how and when to speak to staff. Maybe visitors with particular worries should come in when the usual staff are present.

We must also ensure that nurses employed on the wards are supported - as the trained professionals they are—to give key information to families, and they should be respected when they do. Doing this well is difficult, when understaffing and vacancies leave them time poor and so focused on essential tasks that high quality handover and knowledge of the "script" for each patient can vary, as can confidence in "owning" and imparting the patient's progress report.

Maybe we need to be radical and leave a written or electronic progress summary for patients' families, or we could devote an hour or two a day to email correspondence with them. In many cases families now want proactive, regular updates, given without even asking to speak to anyone. This might help avoid complaints and improve communication, but time spent with patients would suffer.

\section{Competing interests: See www.bmj.com/about-bmj/freelance-} contributors/david-oliver.

Provenance and peer review: Commissioned; not externally peer reviewed.

Follow David on Twitter: @mancunianmedic

1 Oliver D. David Oliver: Taking carers for granted. BMJ 2017;359:j1523. doi:10.1136/bmj. j1523 pmid:28377428.

2 Oliver D. David Oliver: welcoming carers on to the wards. BMJ 2015;359:h4959.pmid: 26385852.

3 Oliver D. David Oliver: When "resilience" becomes a dirty word. BMJ 2017;359:j3604. doi:10.1136/bmj.j3604 pmid:28743685.

4 Royal College of Physicians. Being a junior doctor: experiences from the front line of the NHS. Dec 2016. https://www.rcplondon.ac.uk/file/5197/download?token=SCGrvD5w.

Published by the BMJ Publishing Group Limited. For permission to use (where not already granted under a licence) please go to http://group.bmj.com/group/rights-licensing/ permissions 